\section{ЯКІСТЬ ВИЩОЇ ОСВІТИ В УКРАЇНІ ТА ПОЛЬЩІ}

\section{THE QUALITY OF HIGHER EDUCATION IN UKRAINE AND POLAND}

\author{
БЕРЕЖНА Л. Г., \\ старший викладач кафедри \\ іноземних мов, \\ Донецький державний \\ університет управління
}

\author{
BEREZHNA L., \\ Senior Lecturer of the Department \\ of Foreign Languages, \\ Donetsk State University of \\ Management
}

У статті розкрито одну із стратегічних иілей створення єдиного європейського простору вищої освіти - забезпечення якості вищої освіти. Проаналізовано документи щуодо подальшого розвитку системи забезпечення якості вищої освіти в Украӥні та Польщі. Визначено організаційно-правові механізми забезпечення якості вищої освіти України у порівнянні з Польщею.

Ключові слова: вищза освіта, «англійська» модель якості освіти, «франиузька» модель якості освіти, Начіональне агентство 3 забезпечення якості вищої освіти, Польська Акредитаційна комісія.

В статье раскрыта одна из стратегических ичелей создания единого европейского пространства высшего образования - обеспечение качества высшего образования. Проанализированы документы по дальнейшему развитию системы обеспечения качества высшего образования. Определены огранизационно-правовые механизмы обеспечения качества высшего образования Украины по сравнению с Польшей.

Ключевые слова: высшее образование, «английская» модель качества образования, «франиузская» модель качества образования, Национальное агентство по обеспечению качества высшего образования, Польская Аккредитационная комиссия.

In the article one of the strategic goals of creating a main European higher education area - ensuring the quality of higher education have been founded. The documents on the further development of the quality assurance system of higher education have been analyzed. The organizational and legal mechanisms for ensuring the quality of higher education in Ukraine and in Poland have been determined.

Key words: higher education, "English" model of education quality, "French" model of education quality, National Agency for in Higher Education Quality Assurance, Polish Accreditation Commission.

Постановка проблеми. Світ постійно змінюється та зміни є необхідними в усіх галузях буття. Не виключенням є й вища освіта України - вона потребує вдосконалення. Фактично якість освіти в українських закладах вищої освіти перевіряється переважно 
міністерствами, а не замовниками освітніх послуг. Основне завдання освітніх інституцій полягає не в підвищенні власної якості та ефективності, а в успіху формальних звітувань перед органами державного контролю [1].

В той же час такі високорозвинені країни, як США, Канада, європейські країни сприяють підвищенню якості освіти у ЗВО, оскільки це показник не лише для рейтингу закладів, але також і для держави в цілому.

Аналіз останніх досліджень та публікаџій. Багато досягнень присвячено покращенню якості освіти в Україні, наприклад, ЗВО проводять різноманітні заходи регіонального та міжнародного рівнів. Зокрема, на думку I. Іванової (2016), ефективна система для моніторингу та оцінювання якості вищої освіти в Україні буде кращим, якщо ми використаємо європейський досвід [2, с. 148]. Н. Сидоренко (2016) вважає, що внутрішнє забезпечення якості вищої освіти в Україні має бути соціальним та освітнім пріоритетом [3, с. 81]. О. Юзик (2013) стверджує, що якість освіти є однією з умов модернізації системи освіти в Україні в рамках Болонського процесу [4, с. 102].

Якість освіти у вищих навчальних закладах Польщі вивчали Гржегож Мазуркевич та Іоланта Каминска. Впровадження заходів щодо якості освіти ініціалізувала Анна Залевська, Міністр національної освіти Польщі. Гржегож Мазуркевич (2012) у своєму науковому збірнику «Якість освіти. Мультидисциплінарні аспекти» аналізував погляди польських вчених на якість освіти в таких аспектах, як: цінності, бачення, пріоритети; процес навчання та викладання; співпраця [5].

Іоланта Каминска (2016) описує імплементацію реформ у Польщі щодо якості освіти, які обговорювались на засіданнях урядового комітету та органів місцевого самоврядування. Насправді вони стосуються розвитку програмного забезпечення, управління та змін у галузі професійної освіти. На конференції Анна Залевська (2016), Міністр національної освіти Польщі, порушила питання якісної освіти в початкових та середніх школах.

Цікаво знати, що з 1982 року польські вчителі мають повноваження - дотримуються дисциплінарних правил, які захищають їх права, захищають права батьків та дітей. В Україні наразі обговорюються ці пункти.

Метою статmі $\epsilon$ аналіз європейської системи якості освіти («англійської» та «французької») освітніх моделей та роль національних агентств. На основі аналізу визначити складові рейтингу світових 
університетів. Проаналізувати основні документи про освіту в Україні Закон України «Про вищу освіту», у Польщі - «Закон про вищу освіту Республіки Польща». На основі аналізу сформулювати можливість організації діяльності Національного агентства із забезпечення якості вищої освіти та Польської Комісії з акредитації в Україні.

Виклад основного матеріалу дослідження. У наш час усі країни Європи хочуть мати свідомих студентів, студентів з глибокими знаннями, що сприятиме підвищенню рівня знань у сфері вищої освіти. Це дозволить державі конкурувати 3 іншими державами, дбати про соціальноекономічний, політичний та культурний розвиток. Якість освіти як об'єкт управління $є$ одним 3 найважливіших показників і відповідно до нього визначається ефективність системи освіти будь-якої держави та ефективність управління на міжнародному рівні.

Цікаво знати, що в Свропі існує дві моделі якості освіти: «англійська» та «французька». Під час впровадження «англійської» моделі, якість освіти базується на внутрішній самооцінці академічної спільноти. «Французька» модель базується на зовнішньому оцінюванні вищих навчальних закладів відповідно до ії актуальності для суспільства.

Лілія Гриневич, яка у 2018 була міністром освіти і науки України, наголосила, що Міністерство освіти планує покращити якість освіти у вищих навчальних закладах шляхом інтеграції до європейського простору вищої освіти та наукових досліджень. У той же самий час Л. Гриневич пропонує шляхи заохочення кращих студентів до вищих навчальних закладів: представлення результатів зовнішнього незалежного оцінювання, єдиний професійний тест на магістерську програму, цільове розміщення державного замовлення. НАЗЯВО щороку готує та публікує звіт про якість вищої освіти в Україні, ï відповідність завданням сталого інноваційного розвитку суспільства. У звіті про його діяльність формуються пропозиції щодо законодавчого забезпечення якості вищої освіти та надсилає ці документи до Верховної Ради України, президентові України, до Кабінету Міністрів України та до вищих навчальних закладів для їх обговорення та належного реагування.

Склад Національного агентства із забезпечення якості вищої освіти становить сформовану групу із забезпеченням представництва не більше як однієї особи з конкретного напрямку знань і включає:

1) три особи, обрані від представників всеукраїнських асоціацій роботодавців;

2) дві особи серед аспірантів першого або другого курсу; 
3) не менше одного представника 3-поміж людей, які мають основне робоче місце в Національній академії наук України; Національній галузевій академії наук (по одному представнику від кожної академії);

- вищий навчальний заклад державної форми власності;

- вищий навчальний заклад комунальної власності;

- вищий навчальний заклад у приватній власності.

Особа може бути висунута кандидатом у члени НАЗЯВО особою, яка згадується у частині другій цієї статті, або шляхом самовисування.

В Україні команда проєкту «Довіра» пропонує свій національний веб-портал про якість забезпечення вищої освіти в Україні за підтримки Tempus IV Європейського Союзу [6]. Портал містить п’ять вкладок головного меню: домашня сторінка, освітні ресурси, набір цінностей, рейтинги, довідка. Портал забезпечує відкрите звітування учасників освітніх процесів про власні академічні та наукові досягнення. Це є гарною ідеєю. Однак цей портал, поки що, заповнений не повністю.

Республіка Польща має достатньо врегульовану систему надання якісної освіти. В 2018 у Польщі було 393 університети, 2949 факультетів та 5154 курси [7]. Проаналізувавши Закон про вищу освіту в Республіці Польща, зроблено висновки, що існує інший підхід до формування комісій 3 питань якості освіти, їх склад та діяльність у цій європейській державі. Зокрема, Польська акредитаційна комісія створюється під час акредитації університетів та їх перевірки якості освіти. Його термін - чотири роки. Розділ VI статті 48 цього ж закону погоджує назву комісії (у Польщі Польська акредитаційна комісія призначає компетентного Міністра 3 питань вищої освіти) та його членів: принаймні вісімдесят і не більше дев'яносто членів призначаються через міністра вищої освіти; президент студентського парламенту Республіки Польща, який також є членом Комісії. Члени Комісії призначаються з числа кандидатів, представлених Радою, конференцією ректорів академічних шкіл Республіки Польща, Національним коледжем аспірантів як і основними науковими асоціаціями та організаціями роботодавців. Будь-який вчитель, який має принаймні ступінь доктора філософії, працює у ЗВО як на основному робочому місці (ця вимога не застосовується до представників організацій роботодавців) може бути членом Комісії.

Вимога Міністра освіти враховується Комісією. Там є представники всіх галузей освіти та щонайменше $30 \%$ жінок у його складі. $€$ цікава вимога, якої у нас немає - члени Комісії не мають досягти більше 
сімдесяти років. Термін дії Комісії починається 31 січня і триває чотири роки.

Ректор може на прохання члена Комісії, який є викладачем 3ВО, звільнити його повністю або частково від обов'язку проводити заняття. Закон про вищу освіту Республіки Польща чітко визначає основні завдання польської мови.

У Польщі заявники можуть скористатися веб-порталом «Вибрати освіту» [7], який має базу всіх вищих навчальних закладів Польщі. Портал підготовлений Міністерством наук та вищої освіти Польщі. Портал призначений для кожної людини, яка цікавиться пропозиціями вищої освіти в Польщі, перш за все, для випускників шкіл та кандидатів на навчання. Портал містить інформацію про всі вищі навчальні заклади в Польщі, інформацію про напрямки навчання, які можна вибрати, оцінку напрямків навчання у певному університеті. Напрямки оцінюють експерти з Польської акредитаційної комісії. Коли курсор знаходиться над кожним напрямком, проводиться оцінка та з'являється програма: яскрава, позитивна, умовно негативна. Існує легенда оцінок в різні кольори навпроти наукового підрозділу вищого навчального закладу: синій яскрава, найвища оцінка; зелений - позитивна оцінка; жовтий - умовна оцінка; червоний - негативна оцінка; сірий - відмова від оцінки; яскравожовтий - оцінка в прогрес; відсутність кольору - без оцінки. Ця система діє 31 листопада 2011 року.

Портал також містить інформацію про підготовку бакалаврів, магістрів як установи післядипломної освіти. Портал має пошукову систему, якою легко користуватися. Портал «Виберіть освіту» містить лише перевірену інформацію, оскільки вона $\epsilon$ офіційним порталом Міністерства науки та вищої освіти Польщі.

Висновки та перспективи подальших досліджень. Досліджено діяльність «англійської» та «французької» моделі якості освіти та робота порталу на забезпечення якості вищої освіти. Встановлено, що роботу порталу має бути надалі впроваджено; офіційні веб-сайти ЗВО надають інформацію про оцінку курсів та навчальних програм у кольорах (як це має місце в Польщі).

Наступні дослідження можуть стосуватися особливостей використання виборів членів Національного агентства із забезпечення якості вищої освіти щодо використання досвіду роботи Польської акредитаційної комісії. 


\section{Лimepamypa:}

1. Довіра. Kontseptsiia zabezpechennia yakosti vyshchoi osvity Ukrainy. (2018). Retrieved. URL: http://dovira.eu/images/QA_concept_Final.pdf. (дата звернення: 01.08.2020).

2. Ivanova, S. V. (2016). Yevropeiskyi dosvid stvorennia efektyvnoi systemy kontroliu ta otsinky yakosti vyshchoi osvity v Ukraini. Naukovi zapysky. Seriia: pedahohika, 3, pp. 148-155.

3. Sydorenko, N. (2016). Vnutrishnie zabezpechennia yakosti vyshchoi osvity Ukrainy yak suspilno-osvitnii priorytet. Derzhavne upravlinnia ta mistseve samovriaduvannia, 4 (31), pp.81-85.

4. Yuzyk, O. (2009). Yakisna osvita - odna iz umov modernizatsii systemy osvity v Ukraini v ramkakh Bolonskoho protsesu. Nova pedahohichna dumka. Materialy XI Mizhnarodnoi naukovo-metodychnoi konferentsii "Zabezpechennia nastupnosti zmistu $\mathrm{v}$ systemi vyshchoi ta pisliadyplomnoi osvity" 2013. Rivne.

5. Mazurkiewicz, G. (2012) Jakosc educacji. Rosnorodne perspektytwy. 2012. Krakow. URL: https://www.npseo.pl/data/documents/3/263/263.pdf. (дата звернення: 01.08.2020).

6. Portal zabezpechennia yakosti vyshchoi osvity. (2016). URL: http://portal.dovira.eu.

7. Wybierz Studia. (2018). URL: http://wybierzstudia.nauka.gov.pl/ pages/search/wizard.

8. Prawo o szkolnictwie wyszym w nauce. Warszawa, dnia 30 sierpnia 2018 r. Poz.1668 Ustawa z dnia 20 lipca 2018 r. (2018). URL: https://www.uw.edu.pl/wpcontent/uploads/2018/09/ustawa.pdf.

In the article one of the strategic goals of creating a main European higher education area - ensuring the quality of higher education have been founded. The documents on the further development of the quality assurance system of higher education have been analyzed. The organizational and legal mechanisms for ensuring the quality of higher education in Ukraine and in Poland have been determined.

As a result of strengthening the globalization process, education becomes a key factor of peace, international democracy, global social integration, develops as a service market and in the training of professionals to international standards. There is a need to use international education standards and quality assessment criteria in the field of education. 
Various approaches and mechanisms of quality control of the received education are in the state of research and development of the quality management model of higher education. In this process, the subjects are the state bodies of education quality management, which form only part of the mechanism of public administration, and the object is the components of the education system: material, technical, scientific, methodological and human resources.

In order to improve and improve the quality of higher education in Ukraine, various activities are systematically carried out. One of them is the accreditation of education programs by the National Agency for Quality Assurance in Higher Education. And in Poland Polish Accreditation Commission. Accreditation of educational programs is a verification of compliance with the Licensing conditions and standards of higher education.

The Presidium of the National Academy of Pedagogical Sciences of Ukraine approved the new version of the Concept of introduction of media education in Ukraine. The main purpose of the Concept of introduction of media education in Ukraine is to promote the development of an effective media education system in Ukraine, which should become the basis of humanitarian security of the state, development and consolidation of civil society, counteract external information aggression, comprehensively prepare children and young people for systematic cooperation, to shape media literacy and media culture among citizens according to their age, individual and other characteristics. 